\title{
Türkiye Ekonomisi İçin Finansal Çevrimler ve İş Çevrimleri: Granger Nedensellik Testi*
}

\author{
Financial and Business Cycles for Turkish Economy: Granger Causality Test
}

\section{Aycan Pervin DEĞNELI' ${ }^{1}$}

${ }^{1}$ T.C. Hazine ve Maliye Bakanlığı, Vergi Denetim Kurulu Başkanlığı aycanadegneli@gmail.com Orcid ID: 0000-0002-1813-5531

$\begin{array}{ll}\text { Makale Bilgisi: } & \text { Araştırma Makalesi } \\ \text { Geliş Tarihi: } & 13.03 .2020 \\ \text { DüzeltmeTarihi: } & 31.05 .2020 \\ \text { Kabul Tarihi: } & 05.06 .2020\end{array}$

\section{Özet}

Dünya ekonomisi oldukça sıkı bir entegrasyon sürecine girmiştir. Ekonomide meydana gelen dalgalanmalarm anlaşılması, finansal piyasalar ve ekonominin bütünü açısından oldukça önemlidir. Bu çalışmanın amacı Türkiye ekonomisinde iş çevrimleri ve finansal çevrimler arasındaki ilişkinin analiz edilmesidir. Bunun için 2003:1 - 2015:12 dönemine ait aylık veriler kullanılarak Türkiye ekonomisinde iş çevrimleri ve finansal çevrimler arasındaki etkileşimler Granger Nedensellik Testi ile saptanmaya çalışılmıştır. Elde edilen sonuçlara göre reel kredi hacmi endeksi ve konut fiyatlar endeksinin makroekonomik değişkenler üzerinde dalgalanmalara sebep olan açıklayıcı değiş̧ken olarak öne çıktı̆̆ görülmektedir. Çalışmadan elde edilen diğer bir sonuç ise finansal değişkenlerin birbirleri arasındaki ilişkiler ile ilgilidir. Buna göre konut fiyatlar endeksi ve reel kredi hacmi endeksi arasında çift yönlü bir nedensellik ilişkisi bulunmaktadır. Makroekonomik değişkenler ve finansal değişkenler arasındaki bu nedensellik ilişkisi göz önünde bulundurulduğunda iş çevrimleri ve finansal çevrimler üzerine yapılacak çalışmalarda reel kredi hacmi endeksi ve konut fiyatları endeksinin ekonomideki iş çevrimlerinin analiz edilmesinde açıklayıcı değişken olarak kullanılabileceŏi sonucuna ulaşılmıştır.

Anahtar Kelimeler: Finansal Çevrimler, İş Çevrimleri, Türkiye Ekonomisi, Granger Nedensellik Testi

JEL kodları: E30; E32; G10

\author{
Article Info: \\ Date Submitted: \\ Date Revised: \\ Date Accepted: \\ Research Article \\ 13.03.2020 \\ 31.05.2020 \\ 05.06.2020
}

\begin{abstract}
The world economy has moved towards closer integration. Understanding the fluctuations that occur in the economy is important for financial markets and whole of the economy. The aim of this study is to analyse the interactions of financial cycles and business cycles for Turkish economy. In able to confirm this by using monthly data between 2003:1 - 2015:12 the interactions of financial cycles and business cycles for Turkish economy have analysed with Granger Causality Test. According to the results, real credit volume index and house price index stand out as the explanatory variable causing fluctuations on macroeconomic variables. Another result obtained from the study is about the relationships between financial variables. Accordingly, there is a bidirectional causality relationship between the house price index and the real credit volume index. Considering this causality relationship between macroeconomic and financial variables, it is concluded that the real credit volume index and house price index can be used as a descriptive variable in the analysis of business cycles in the economy.
\end{abstract}

Keywords: Financial Cycles, Business Cycles, Turkish Economy, Granger Causality Test

JEL codes: E30; E32; G10

\footnotetext{
* Çalışma etik kurul ve yasal izin alınması kapsamında değildir. İntihal raporu alınmıştır.
} 


\section{GİRIŞ}

Ekonomik krizlerin sağladığ1 fırsatların öğrenilmesinde şüphesiz en iyi örnek çok büyük bir ekonomik kriz olan Büyük Buhrandır (Great Depression). Büyük Buhran mikroekonomik çalışmalardan farklı bir alan olarak makroekonominin ve özel olarak Keynesyen bakış açısının gelişmesinde önemli bir rol oynamıştır. Günümüzde ise, 2007 yılında başlayan küresel finansal krizle birlikte ikinci bir Büyük Buhrana doğru gidilip gidilmediği ve aynı zamanda iş çevrimleri ile başa çıkmakta zaman içerisinde denenmiş politikaların yeniden düşünülebileceği ve bu noktada çıarılması gereken yeni derslerin olup olmadığı gibi birçok konuda endişeler ortaya çıkmıştır. Gerek Keynes' den önce gerek Keynes' den sonra makroekonomik teorideki birçok önemli gelişmenin merkezinde ekonomilerin neden negatif çıktı büyüme periyotlarına maruz kaldıkları (recessions) ve ciddi ekonomik daralmaların nasıl açıklanabileceği (depressions) soruları yer almaktadır. İki yüz yıldan fazla zamandır tartışılmasına rağmen burada neyin durgunluklara (recessions) ve buhranlara (depressions) neden olduğu konusunda genel bir uzlaşma halen sağlanamamıştır. İş çevrimlerinin nedenleri üzerine bu tartışmalar makroekonomik düşüncenin gelişiminde anahtar sorular olmaya devam etmektedir. Makroekonomiyi bugün uygulandığ 1 şekilde kavramak ve gelecekte nerede olacağını anlamak için makroekonomik dalgalanmalar yoluyla görülen ekonomik faaliyetlerdeki değişimi ve altında yatan teorik zemini anlamak çok önemlidir (Knoop, 2010: 3-5).

İktisadi dalgalanmalar ve bu dalgalanmaların analiz edilmesinde iş çevrimlerinin tarihlerinin ve sürelerinin belirlenmesi oldukça önemlidir. Bu konuda literatüre çok önemli katkılar sağlayan Burns ve Mitchell (1946) çalışmalarında iş çevrimlerinin temellerini belirlemek istemişlerdir.

Burns ve Mitchell (1946) iş çevrimlerini genelde piyasa ekonomisinin olduğu ülkelerin toplam ekonomik aktivitelerinde ortaya çıkan bir çeşit dalgalanma olarak tanımlamışlardır. (Burns ve Mitchell, 1946: 3).

NBER tanımına göre bir durgunluk (recession) dönemi iki veya daha fazla çeyrek birbirini takip eden negatif çıktı büyümesi dönemidir. Genişleme (expansion) dönemi ise iki veya daha fazla çeyrek birbirini takip eden pozitif çıktı büyümesi dönemidir. Genişleme tepe noktası zamanda bir noktadır ve çıtı seviyesinin maksimum olduğu seviyeyi gösterir. Tepe noktasından sonra çıktı seviyesi düşmeye başlar. Bundan dolayı, durgunluğun başlangıç zamanı genişleme tepe noktasıdır. Benzer şekilde, durgunluğun dip noktası zaman içerisinde bir noktadır ve çıktının artmaya başlamadan önceki en düşük seviyesini belirtir. İş çevrimleri periyodik değildir; buna göre iş çevrimlerinde durgunluklar ve genişlemeler birbirlerini düzenli ve öngörülebilir bir motifte takip etmezler. İş çevrimleri zaman içerisinde boyutları ve süresi bakımından önemli farklılıklar gösterirler. (Knoop, 2010: 15)

Lucas iş çevimlerinin birbirleriyle özdeş olmadığını, ancak bu çevrimlerin ortak özelliklerinin bulunduğunu, siyasal ve kurumsal yönden belirli özelliklere sahip dönemler veya ülkelerden ziyade piyasa ekonomilerine yön verecek nitelikte genel kurallar zeminine oturtulmuş iş çevrimi açılamalarının sağlanmasının bu konuda çalışmalar yapan ekonomistler için oldukça çekici bir konu olduğunu belirtmektedir (Lucas, 1977: 10). 
Altuğ (2010) belirttiği üzere, ekonomistler iş çevrimleri süresince ekonomik değişkenler arasındaki birlikte hareketlerin incelenmesinde makroekonomik değişkenin toplam ekonomik aktiviteye göre yönü ve iş çevriminin dönüm noktalarına göre değişkenin dip/tepe noktalarının zamanlamasını dikkate alan çalışmalar yapmışlardır ve bu çalışmalardan elde edilen ampirik bulgular iş çevrimlerinin stilize gerçeklerini (stylized facts) vurgulamak için kullanılmıştır.

Son yirmi yılı aşkın bir süreyle, finansal piyasalardaki çevrimler büyük ölçüde dünya genelindeki reel ekonomik aktiviteden etkilenmiştir. Modern tarihin en büyük konut balonunu takiben, 1990'ların başında Japonlar son derece ağır bir varlık piyasası çöküşü yaşamışlardır. Uzun süreli kredi patlamalarından sonra Asya'da gelişmekte olan ülkelerin çoğu 1990'lı yılların ikinci yarısında çok ciddi finansal krizlerle karşı karşıya kalmışlardır. 1990'ların sonunda birçok gelişmiş ekonomide hisse senedi piyasalarında görülen patlamaları senkronize çöküşler ve çevrimsel daralmalar takip etmiştir. 2003-2007 yıllarında Amerika ve Avrupa Birliği üyesi pek çok ülkede kredi ve konut piyasasında patlamalar görülmüştür. Bu durum, son kırk yılda küresel ekonominin gösterdiği en iyi performans olarak kayıtlara geçmiştir. Ancak bu periyot sonunda kredi ve varlık fiyatlarındaki çöküşler nedeniyle birçok finansal aksaklıklar ortaya çıkmıştır. Bu süreç Büyük Buhran'dan bugüne görülen en büyük finansal krizi de beraberinde getirmiştir. Bu sebeple finansal çevrimlerin anlaşılması oldukça önemli bir araştırma konusu haline gelmiştir (Claessens vd., 2011a: 3-5).

Finansal çevrimlerin tanımı ile ilgili bir fikir birliği bulunmamakla birlikte terim olarak birbirini takip eden ekonomik genişleme ve daralma dönemleri ifade edilmektedir. Ekonomik dalgalanmalar ciddi mali sıkıntılara ve ekonomik bozulmalara neden olabilmektedir. Bu durum finansal sistemin çevrimle aynı yönde (procyclical) hareket etme durumu ile yakından ilişkilidir. Bu nedenle araştırmacılar iş çevrimleri ve finansal krizleri analiz etmektedirler. Ayrıca çalışmalarda merak edilen önemli konulardan biri de ampirik olarak finansal çevrimlerin en iyi nasıl yansıtılabileceğidir. Dolayısıyla bu konuda, iş çevrimleri ile ilişkilerin açılanması, finansal krizlerle olan bağlantının anlaşılması ve finansal sıkıntıların içeriğinin gerçek zamanlı öngörüsü ve bunun politika rejimleri ile olan bağıntısının anlaşılması oldukça önem arz etmektedir.

Bu çerçevede çalışmanın amacı; finansal çevrimler ve iş çevrimleri arasındaki ilişkinin yönü ve ampirik çalışmalarda hangi finansal ve makroekonomik değişkenlerin açıklayıcı değişken olarak kullanılabileceğini ortaya konulmasıdır. Çalışmada finansal değişkenler olarak Reel Varlık Fiyat Endeksi, Reel Kredi Hacmi Endeksi, Finansal Stres Endeksi, Konut Fiyatları Endeksi; makroekonomik değişkenler olarak Endüstriyel Üretim Endeksi, Tüketici Fiyat Endeksi (TÜFE), Reel Faiz, Reel Efektif Döviz Kuru Endeksi-TÜFE Bazlı, Tüketim Endeksi, Yatırım Endeksi, Hükümet Harcamaları Endeksi, İhracat Endeksi, İthalat Endeksi kullanılmıştır. Türkiye'de 2003:1 - 2015:12 döneminde iş çevrimi ve finansal çevrimler arasındaki etkileşimlerin araştırılması için Granger nedensellik testi kullanılmıştır. Çalışmanın ikinci, üçüncü ve dördüncü bölümlerinde finansal çevrimler ve iş çevrimlerinin ne oldukları, senkronizasyonları ve aralarındaki etkileşimler ile ilgili literatüre yer verilecek olup beşinci ve altıncı bölümlerde ise iş çevrimleri ve finansal çevrimler arasındaki etkileşimler analiz edilip tartışılacaktır. 


\section{FINANSAL ÇEVRIMMLER ve İŞ ÇEVRIMLERI}

Finansal çevrimler ve iş çevrimlerinin kaynağını ve etkilerini inceleyen Claessens vd. (2011a, b), Artis vd. (2011), Auroba vd. (2011), Drehmann vd (2012) çalışmalarda dalgalanmaların türleri, süreleri ve etkileri bakımından farklı sonuçlar elde edildiği görülmektedir. Claessens vd. (2011a, b), Borio and Lowe (2002), Artis vd. (2011), Artis vd (2004), Alvarez vd (2010) çalışmalarda küreselleşme ve ekonomilerin dışa açılı̆̆ı ile birlikte yüksek entegrasyon nedeniyle finansal çevrimler ve iş çevrimleri arasında önemli etkileşimlerin bulunduğu sonucu desteklenmektedir.

Finansal sistemin istikrarının sağlanması birçok politika yapıcı için oldukça önemli bir amaçtır. Son birkaç yılda görüldüğü üzere, istikrarsızlık dönemlerinin kökeninde çoğunlukla yüksek enflasyon ve finansal kuruluşlar tarafından yapılan yetersiz risk yönetimini de içeren zayıf makroekonomik politikalar olduğu görülmektedir. Ancak, finansal dengesizlikler aynı zamanda düşük enflasyon dönemlerinde de görülebilmektedir Birçok sanayileşmiş ülke 1980'lerin sonlarında finansal aşırılıklar yaşamıştır. Bu aşırılıklar, ekonomik genişlemelere yol açmaktan ziyade, ekonomik daralmaları ve 1990'lı yıllarda görülen finansal sıkıntıları beraberinde getirmiştir. 1990'lı yılların ortalarından itibaren de ekonomik genişlemeler güçlü varlık piyasaları ve katı kredi büyümesi ile desteklenmiştir. Gelişmekte olan ülke ekonomilerinin çoğunda, finansal çevrimler belirgindir ve uluslararası sermaye akışından büyük ölçüde etkilenmektedir. Finansal serbestleşme ile özel sektör mali bilançolarında GSYİH'ya göre borç seviyelerinde ve finansal varlıklarında önemli bir artış olduğu görülmektedir. Kredi büyümesi hem altta yatan ekonomik koşullar ve risk algısı hem de varlık piyasaları ve kredi büyümesi arasındaki bağlantının güçlenmesi nedeniyle daha duyarlı hale gelmiştir. Özel sektör harcamaları da artan bir şekilde varlık fiyatlarındaki hareketlere duyarlı hale gelmiştir. Genel olarak, makroekonomi ve finansal sistem gittikçe artan bir şekilde iç içe geçmiştir. (BIS, 2001: 124)

Global Finansal Kriz sürecinde birçok çalışma direkt finansal çevrimlerin belirlenmesine yönelik olmuştur. Aikman vd. (2014) 1870 - 2008 periyodunda 14 gelişmiş ülkede görülen kredi çevrimlerini araştırmışlardır. Claessens vd. (2011a, b) 1960-2007 yılları için 21 gelişmiş ülkenin kredi, konut ve varlık fiyatlarındaki çevrimsel hareketleri analiz etmişlerdir. Her iki analizde de kredi ve konut fiyatlarının yüksek derecede senkronize olduğu sonucuna ulaşılmıştır. Drehmann vd. (2012) 1960-2011 periyodunda 7 gelişmiş ülke için finansal değişkenlerin orta vadeli dalgalanmalarının ölçülmesine yönelik olarak yapay finansal çevrimlerin oluşturulması konusunda çalışmışlardır. Kredi ve konut fiyatlarının kombinasyonunun varlık fiyatlarına göre çok daha iyi sonuçlar verdiğini bulmuşlardır. Ayrıca çalışmalarında, 1980 'lerin ortalarından bu yana finansal çevrimlerin genliğinin yani trend çizgisi yada ortalama değerden çevrimin tepe/dip noktasının ordinat ekseninde oluşturduğu değeri (amplitude) ve süresinin arttığını göstermişlerdir. Aikman vd. (2014) ve Drehmann vd. (2012) sistematik bankacılık krizleri ile finansal çevrimlerin tepe noktaları arasında oldukça güçlü bir ilişki olduğu sonucuna varmışlardır. Literatürde birçok farklı metot olmasına karşın, finansal çevrimlerin iş çevrimlerine kıyasla daha yüksek genlik ve daha düşük frekansa sahip oldukları yönünde benzer sonuçlara ulaşmışlardır (Stremmel, 2015:5).

Claessens vd. (2011a), 1960:1-2007:4 periyodunda 21 gelişmiş OECD ülkesi için finansal çevrimlerin temel özelliklerini analiz etmişlerdir. Bunun için kredi, konut ve hisse senedi 
fiyatları kullanılmıştır. Bulunan sonuçlara göre, finansal aksaklıklar görece daha uzun olma eğilimine sahipken, finansal patlamalar daha kısa olma eğilimindedir. Hisse senetleri ve konut fiyatları çevrimlerinin kredi çevrimlerine göre genellikle daha uzun ve daha belirgin oldukları görülmüştür. Finansal çevrimlerin zamanla değiştiği gözlemlenmiştir. Özellikle hisse senedi çevrimlerinin oldukça kısa olduğu görülmüştür. Ülkeler içinde en yüksek senkronizasyona kredi ve konut fiyatları çevrimlerinin sahip olduğu belirtilmiştir. Kredi ve hisse senetleri çevrimlerinin ise ülkeler arasındaki en yüksek senkronizasyon derecesine sahip olduğu ve zamanla bu oranın arttığı sonucuna ulaşılmıştır.

Finansal çevrimlerle ilgili literatürde yer alan bazı çalışmalarda finansal çevrimlerin belirlenmesine yönelik olarak Detken ve Smets (2004), Goodhart ve Hofmann (2008), Schularick ve Taylor (2012), Aizenman vd. (2013), Borio vd. (2013), Bracke (2013) tarafından varlık fiyatları veya kredi gibi finansal göstergeler kullanılırken, Borio ve Lowe $(2002,2004)$, English vd. (2005), Borio ve Drehmann (2009), Alessi ve Detken (2011) finansal faktörleri erken uyarı sistemlerinde öncü göstergeler olarak kullanılmıştır.

Literatürde çevrimle aynı yönlü (countercyclical) hareket eden kredi büyüklüklerinin tanımlanması için kredi/çıktı açığı (credit-to-GDP gap) gibi kredi ölçülerinin çevrimsel hareketinin etkinliğinin araştırılmasına yönelik çalışmalar da artarak görülmeye devam etmektedir. Drehmann ve Tsatsaronis (2014), Wezel (2014)'a göre bu kredi büyüklügünün çevrimsel hareketi finansal güvenlik açıklarının belirlenmesi için bir erken uyarı göstergesi olarak kullanılmaktadır.

Finansal faktörler iş çevrimlerinin belirlenmesinde önemli bir role sahiptirler. Ancak, yerel finansal sitemler ve uluslararası sermaye akımlarının liberalleştirilmesi gibi durumlarda ise bu rol daha da büyümüştür. Kredi ve varlık piyasalarındaki gelişmeler, tipik iş çevrimi dinamikleri üzerinde önceki yıllara göre oldukça derin bir etkiye sahip olmuştur. Bu gelişmeler bankacılık sektöründe artan sıklıkta krizler görülmesine katkıda bulunmuştur (BIS, 2001: 123).

Kredi ve varlık fiyatlarındaki çevrimler ardışık olarak meydana gelmektedir ve genellikle karşılıklı olarak birbirlerini desteklemektedir. Varlık fiyatları düştügünnde ve ekonomik koşullar kötüleştiğinde, kredi ve varlık fiyatları arasındaki etkileşim daha da güçlü olabilmektedir. 1990'lı yıllar ve sonrasında, özellikle ticari mülkiyet olmak üzere konut fiyatlarındaki hareketler finansal çevrimlerin merkezini oluşturmaktadır. Konut piyasasındaki gelişmeler aynı zamanda finansal çevrimleri de şekillendirmektedir. (BIS, 2001: 126-127).

Günümüzde de geçerliliğini kaybetmemiş birçok çalışmada özellikle kredilere ve kredi çevrimlerine odaklanılmaktadır (Aikman vd. (2014), Schularic ve Taylor (2012), Jordá vd. (2011), Dell'Arriccia vd. (2012)). Buna göre konut fiyatları ve kredilerin birlikte değerlendirilmesi finansal çevrimler, iş çevrimleri ve finansal krizler arasındaki bağlantının temel özelliklerini yakalamanın iyi bir yolu olarak ifade edilmektedir (Borio, 2012: 2-3).

Drehmann vd (2012) göre, finansal çevrimler geleneksel iş çevrimlerinden çok daha düşük frekansa sahiptir. İş çevrimleri genellikle 1 yıldan 8 yıla kadar frekanslar içerirken, tam tersine 1960'lardan bugüne kadar gelişmiş yedi ülkenin finansal çevrimlerinin ortalama uzunluğu yaklaşık 16 yıldır. 
Borio ve Lowe (2002)'ye göre, finansal çevrimlerin uzunluğu ve genliği yani trend çizgisi yada ortalama değerden çevrimin tepe/dip noktasının ordinat ekseninde oluşturduğu değeri (amplitude) politika rejimlerine bağlıdır. Burada üç faktör önem arz edebilmektedir. Bunlar, finansal rejim, para politikası rejimi ve reel ekonomi rejimidir. Finansal serbestleşme, getiri ve risk algısı, risk tutumları ve finansman koşulları arasındaki etkileşimin tamamen kendi kendini güçlendirmesini sağlayarak finansman kısıtlarını zayıflatmaktadır. Para politikası rejimi yakın dönem enflasyonun azaltılması için politikayı sıkılaştırmaya odaklanmaktadır. Reel ekonominin küreselleşmesi ile alakalı en önemli pozitif arz yanlı gelişmeler finansal patlamalara uygun zemin sağlamaktadır. Aynı zamanda enflasyon üzerinde aşağı yönlü baskı koyarken, büyüme potansiyelinin artırılması ve böylece kredi ve varlık fiyatlarındaki patlamalar dolayısıyla para politikaları sıkılaştırılmaktadır. Borio ve White (2003)'e göre, 1980'li yılların ortalarından bugüne finansal çevrimlerin uzunluğu ve genliği belirgin bir şekilde artmıştır. Bu durum gelişmiş ekonomilerin yaklaşık olarak finansal serbestleşme dönemine tekabül etmektedir. Bu tarih aynı zamanda enflasyonun başarılı bir şekilde kontrol edildiği para politikası rejimlerine denk gelmektedir ve küresel ticaret sistemine Çin gibi ülkelerin dahil olmasıyla birlikte, çevrimlerin 1990'lı yıllardan beri özellikle daha geniş ve uzun olduğu görülmektedir. Oysaki bu durumun tersine, Amerika'da 1980'li yılların ortalarından önce finansal çevrimler ve iş çevrimlerinin uzunluk ve genlik olarak benzer oldukları görülmektedir.

Geçtiğimiz otuz yıl süresince, dünya ekonomisi oldukça sıkı bir entegrasyon sürecine girmiştir. Uluslararası ticaret akışı önemli ölçüde artmıştır. Gelişmiş ve gelişmekte olan ekonomilerdeki finansal piyasalar giderek daha entegre hale gelmiştir. Şimdiye kadar nispeten yalıtılmış dünya ekonomisinin önemli bir kısmı serbest ticaret ve sermaye akımlarına açlmış ve Avrupa kıtasındaki ülkeler tek bir para birimini kabul etmişlerdir. Bu gelişmeler yalnızca ulusal iş çevrimi özelliklerinde değil, aynı zamanda onların senkronizasyon özelliklerindeki değişikliklerin artma olasılığını da beraberinde getirmektedir (Artis vd., 2011: 2).

\section{FINANSAL ÇEVRİMLER ve İŞ ÇEVRIMLERİ SENKRONİZASYONU}

Auroba vd (2011) yapmış oldukları çalışmada G7 ülkeleri için 1970-2009 periyodunda geçen 40 yıllık sürede önemli küresel çevrimlerin izlenmesi üzerinde çalışılmıştır. Küresel iş çevrimi ölçütü olarak ortak bir reel G7 aktivite faktörü bulunmuştur. Bu ortak faktör ile ülkeler arasındaki değişkenliğin önemli bir kısmı açıklanmıştır. Ortak G7 faktörü ve ülkelerin kendilerine özgü faktörleri ulusal ekonomik aktiviteyi şekillendirmede farklı zamanlarda farklı roller üstlenmişlerdir. G7 iş çevrimi senkronizasyonun derecesi ülke faktörleri arasında zamanla değişmektedir.

Artis vd (2011) 1880-2006 yılları için tarihsel uluslararası iş çevrimlerini analiz etmişlerdir. Buna göre, Avrupa ve İngilizce konuşan, Anglosakson, grupta ikinci Dünya Savaşı sonrasında ticaretteki artış ile iş çevrimi senkronizasyonu derecesinde bir artış görülmektedir. Diğger ülke gruplarında ise ülkelerin kendine özgü şokları daha baskındır.

Artis vd (2004) Almanya, Fransa, İtalya ve İngiltere, Amerika Birleşik Devletleri için 1960-2001 periyodunda tepe ve dip noktaları ile iş çevrimleri süresinin belirlenmesine ilişkin Markov zinciri yaklaşımı ile alternatif bir yöntem geliştirmek adına algoritma oluşturulmuştur. Buna 
göre Avrupa bölgesinde yüksek senkronizasyon gözlemlenmiştir. Klasik çevrimler kullanılarak Almanya, Fransa ve İtalya ülke çiftlerinin uyumu incelenmiş ve bu uyumun da yüksek olduğu görülmüştür.

Cuevas vd (2002) çalışmalarında 1981-2001 periyodunda Meksika ve onun ticaret ortakları (NAFTA) arasında iş çevrimleri senkronizasyonu derecesindeki değişimleri incelemişlerdir. Buna göre, zamanla senkronizasyonun arttı̆̆ sonucuna ulaşmışlardır.

Male (2011) tarafından 1980-2004 periyodunda gelişmekte olan ülkeler için iş çevrimleri özellikleri ve senkronizasyonu analiz edilmiştir. Buna göre, İş çevrimleri dönüm noktaları gelişmekte olan diğer ülkelere göre Latin Amerika ve Asya ülkeleri arasında daha senkronizedir. Bölge içinde ve bölgeler arasında açık bir uyum bulunmamıştır, ancak bazı gelişmekte olan ülkeler ABD ve Japonya ile yüksek derecede uyum göstermektedirler.

Rana (2007) tarafından 1989:1-2004:12 periyodunda Doğu Asya iş çevrimleri senkronizasyon derecesindeki değişimler analiz edilmiştir. Buna göre, ikili ticaret ilişkilerindeki artış ve para politikası koordinasyon derecesi incelenen Asya ülkeleri iş çevrimi senkronizasyonu üzerinde özellikle finansal kriz sonrası pozitif bir etkiye sahiptir. Çin iş çevrimleri ise diğerlerinden farklı özellikler sergileme eğilimindedir.

Alvarez vd (2010) yapmış oldukları çalışmada Almanya, Fransa, İtalya ve İspanya için 1980:12008:4 periyodu için dört önemli Avrupa bölgesi ülkesinde GSYİH çevrimlerinin yüksek derecede birlikte hareket ettikleri görülmüştür. Ülkeler arasındaki birlikte hareketler çoğunlukla eş zamanlıdır, ancak İspanya' daki çevrimler diğer ülkelere göre bir yada iki çeyrek önce olma eğilimindedir. Konut piyasası çevrimlerinde birlikte hareketliliğin zayıf olduğu görülmüştür. Bunun nedeni olarak, toprak uygunluğu ve düzenlemeleri gibi ülkeye özgü yerel değişkenlerin önemli rol oynadığı belirtilmiştir. Ülkeler arasındaki nominal fiyat ilişkisinin zayıf olduğu belirtilmiştir. Ülkeler arasındaki güçlü GSYİH ilişkileri daha çok Avrupa Para Birliği periyodunda görülmektedir. Bu durum büyük olasılıkla ticaret akışının artan önemini yansıtmaktadır. Ortak para politikası periyodunda, muhtemelen mortgage faiz oranlarındaki yakınsama nedeniyle, güçlü ilişkiler konut yatırımı değişkeninde de görülmektedir. Ancak, konut sektöründe fiyatların birlikte hareketliliğinin reel değişkenlere göre daha zayıf olduğu sonucuna ulaşılmıştır.

Hirata vd (2013) 1971:1-2011:3 periyodunda ülkeler arası konut çevrimleri (housing cycles) senkronizasyonunun nasıl olduğunu anlamak için korelasyonlar, uyum indisleri ve ulusal konut fiyatlarının küresel ve ülkelere özgü bileşenlerinin analiz edilmesine yönelik olarak varyans ayrıştırma metotları kullanmışlardır. Korelasyon sonuçlarına göre, gelişmiş ekonomilerde konut fiyatları birlikte hareket etme eğilimindedirler. Konut fiyatları zamanla daha senkronize olmaktadır. Konut çevrimleri uyum derecesi ve küresel konut fiyatı faktörü tarafından açıklanan konut fiyatlarının varyanstaki payı küreselleşme periyodunda artış göstermiştir. Küresel faiz oranı şokları küresel konut fiyatları üzerinde önemli etkilere sahip olma eğilimindedir. Bu bulgu 2007-2009 küresel finansal kriz öncesinde düşük faiz oranları ile para politikasına sahip gelişmiş ekonomilerde özellikle Amerika'da konut fiyatlarının önemli bir etkisinin olduğunu göstermektedir. Ancak faiz oranlarındaki dalgalanmaların tam olarak nedeni net değildir. Buna göre, küresel para politikası şokları küresel konut fiyatları hareketleri üzerinde ölçülebilir bir etkiye sahip olarak görülmemektedir. Diğer bir değişle, geçtiğimiz 10 yıl içerisinde gelişmiş ülkelerdeki konut fiyatlarının patlama-çökme 
davranışlarının yegâne nedeninin para politikası olmadığı ifade edilmektedir. Küresel ve bölgesel iş çevrimleri üzerine yapılan bu analizde, bölgesel iş çevrimleri daha belirgin hale gelmiştir. Özellikle 1980'lerin ortalarından beri bölge içi ticaret ve finansal bağlantıların hızla geliştiği yerlerde bölgesel iş çevrimleri daha belirgin hale gelmiştir. Bölgesel faktörler özellikle geçen 25 yıl süresince Kuzey Amerika, Avrupa, Okyanusya, Asya bölgelerindeki iş çevrimleri değişkenliğinin büyük bir kısmını açıklamıştır. Hirata vd (2013)'e göre ülkeler arasında finansal çevrimler yüksek derecede senkronize görünmesine rağmen, küresel seviyede yüksek senkronizasyonlu iş çevrimlerine dönüşmemektedir.

Claessens vd. (2011b) iş çevrimleri ve finansal çevrimler arasındaki etkileşimleri analiz ettikleri çalışmalarında 1960:1-2007:4 periyodunu kapsayan 21'i gelişmiş, 23'ü gelişmekte olan 44 adet ülkeye ait 200 'den fazla iş çevrimi ve 700 'den fazla finansal çevrim üzerinde çalışmışlardır. Çalışmada iş çevrimleri ve finansal çevrimler arasındaki etkileşimler analiz edilmiştir. İş çevrimlerini karakterize etmek için temel değişken olarak çıktı kullanılmıştır. Çalışmada çıktının yanı sıra analiz edilen makroekonomik değişkenler ise tüketim, yatırım, endüstriyel üretim ve işsizlik oranıdır. Finansal çevrimlerin analizinde ise kredi, ev ve hisse senedi fiyatları kullanılmıştır. Finansal ve iş çevrimlerinin dönüm noktalarının tanımlanması için iş çevrimi teorisinde yer alan Burns ve Mitchell (1946) tarafından ortaya atılan "klasik" yöntem kullanılmıştır. Ayrıca, serilerin logaritmik düzeyde dönüm noktalarının belirlenebilmesi için de Harding ve Pagan (2002a) tarafından ortaya atılan ve Bry ve Boschan (1971) tarafından geliştirilen "BB algoritması" kullanılmıştır. Aynı zamanda çalışmada iş çevrimleri ve finansal çevrimler arasındaki etkileşimler için sabit etkiler modeli ile çeşitli Panel regresyonlar yapılmıştır. İlgili makaleden elde edilen bulgulara göre, iş çevrimleri hisse senetlerindeki çevrimlere göre kredi ve konut fiyatlarındaki çevrimler ile daha yüksek derecede senkronizasyon sergilemektedir. Finansal aksaklıklara eşlik eden durgunluklar diğer durgunluklara göre daha uzun ve daha derin olma eğilimindedir. Kredi ve konut fiyatları patlamalarıyla ilişkili genişleme dönemleri daha güçlü çıktı büyümesi ile ilişkilidir. Finansal çevrimler iş çevrimlerine göre daha uzun, daha derin ve daha şiddetlidir. Finansal çevrimler ve iş çevrimlerinin her ikisi de gelişmekte olan piyasalarda gelişmiş piyasalara oranla daha belirgindir. Finansal inişler (downturns) ortalamadan daha düşük çıktı büyümesi ile ilişkilidir. Finansal piyasalardaki çıkışlar (upturns) genellikle daha hızlı ekonomik genişlemelere karşılık gelmektedir. Çıktıdaki çevrimler kredi ve konut fiyatlarındaki çevrimler ile yüksek derecede senkronizasyon eğilimindedir. Buna karşın hisse senetlerindeki çevrimlerle büyük ölçüde ortak özellik sergilememektedir. Kredi ve konut fiyatlarındaki hızlı büyüme ile birleşen genişlemeler daha güçlü olma eğilimine sahipken, finansal aksaklık dönemlerine eşlik eden durgunluklar daha uzun ve derin olma eğilimindedir.

\section{FINANSAL ÇEVRIMLER İLE MAKROEKONOMIKK ÇEVRIMLER ARASINDAKİ ETKILEŞIMLER}

Makroekonomik politika analizi ve risk yönetimi piyasalar ve ülkeler arasında bulunan artan bağımlılı̆̆ı dikkate almayı ve ulusal ekonomik konuları global bir bakış açısıyla değerlendirmeyi gerekli kılmaktadır. Bu durum kaçınılmaz olarak birçok farklı aktarım kanalının dikkate alınması gerektiği anlamına gelmektedir. Literatürdeki birçok çalışma hızla artan finansal piyasa entegrasyonunun, sıkı finansal ve reel uluslararası bağımlılı̆̆ tetiklediğini öne sürmektedir (Dées vd., 2007: 2). 
Dées vd. (2005) 1979-2003 periyodunda 26 ülke için ülkelere özgü yerel değişkenler ile ülkelerin vektör hata düzeltme modelleri arasındaki bağlantının kurulmasına yönelik olarak bir global model oluşturmuşlardır. Çalışmada yalnızca ticaret ilişkileri değil aynı zamanda faiz oranları, hisse senetleri fiyatları ve döviz kurları gibi finansal bağlantıları da içeren şokların aktarım mekanizmaları üzerinde durulmuştur. Elde edilen bulgular finansal şokların ABD'den Avrupa bölgesine doğru etkilerinin artarak çok hızlı bir şekilde iletildiğini göstermektedir. Hisse senedi ve tahvil piyasalarının ise reel çıktı ve enflasyona kıyasla daha senkronize oldukları görülmektedir. Aynı zamanda petrol fiyatlarındaki şokun enflasyon üzerindeki etkisi istatistiksel olarak anlamlı iken, çıtı üzerindeki etkisi sınırlı kalmıştır. Buna karşılık, ABD para politikasının Avrupa bölgesi çıktı ve enflasyon üzerine etkileri sınırlıdır ve istatistiksel olarak çok anlamlı değildir.

ABD'deki bir şokun Avrupa üzerinde doğrudan etkilere sahip olmasının yanı sıra dolaylı etkilere sahip olabilmesinin nedeni Dées vd. (2005)'e göre, ilgili şokun dünyanın geri kalanı üzerindeki etkilerinin zamanla $\mathrm{ABD}^{\prime}$ ye yansıması sonucunda şokun etkilerinin daha da artmasıdır. Şoklar yalnızca ticaret yoluyla değil, önemli ölçüde finansal değişkenlerin reel değişkenler üzerindeki yayılma etkileri yoluyla aktarılmaktadır.

Kore ekonomisinin uluslararası bağlantılarının analiz edilmesine yönelik olarak yaptıkları çalışmanın sonucunda, Greenwood-Nimmo vd. (2012a) reel ekonomi ve finansal piyasaların petrol fiyatlarındaki değişime karşı oldukça duyarlı olduğunu öne sürmüşlerdir.

1979:2-2011:2 periyodunda 38 ülke ve bölgeleri için ticaret, finans ve emtia fiyatları yolu ile makroekonomik şokların ülkeler arasındaki aktarımı üzerine çalışan Cashin vd. (2012)'nin elde ettikleri sonuçlara göre, MENA ülkeleri Çin'deki gelişmelere Avrupa Bölgesi ve ABD'deki şoklara göre daha duyarlıdır.

Bayoumi ve Bui (2010)'a göre, 2008 krizi 1930'lardan bu yana ABD'de görülen en büyük global yavaşlamaya neden olan şokları barındırmıştır. Dolayısıyla, bu süreçte uluslararası iş çevrimlerinin önemi bir kez daha ortaya çıkmıştır. Elde edilen sonuçlara göre, uluslararası iş çevrimleri, başta emtia fiyatlarını yansıtan global şoklar ile birlikte büyük ölçüde ABD finansal şokları tarafından meydana gelmektedir. Büyümenin yayılmasında, diğer gelişmiş ekonomiler ve bölgeler daha küçük ve bölgesel bir rol üstlenmektedir.

Dées, (2015) tarafından 1987-2013 periyodunda 38 ülke için global düzeyde iş çevrimleri ve finansal çevrimler arasındaki bağlantı analiz edilerek reel ekonomik dalgalanmalar ve finansal değişkenlerin rolü değerlendirilmiştir. Çalışmada birçok ülke ve bölge için reel ekonomik aktiviteye kredi ve varlık fiyatlarının katkısı analiz edilmiştir. Elde edilen sonuçlara göre, reel ekonomik dalgalanmaların açıklanmasında kredi ve varlık fiyatlarının önemi görece olarak büyüktür. Ancak global finansal krizden bu yana anlamlı olarak bir artış gözlemlenmemiştir. İş çevrimi dalgalanmaları üzerine finansal şokların uluslararası aktarımının aynı zamanda büyük ve kalıcı olma eğiliminde olduğu belirtilmiştir.

Galesi ve Sgherri (2009) yaptıkları çalışmalarında, 1999 - 2008 periyodu için ABD ve 17 gelişmiş Avrupa ülkesi ile 9 gelişmekte olan ekonomi için ülkelere özgü modeller kullanmışlardır. Her ülke modeli birbirine ülkelere özgü dış değişkenler ile bağlanmıştır. Elde edilen bulgular finansal piyasalar genelinde hisse senedi fiyatlarının önemli ölçüde birlikte hareketlerini göz önüne sermektedir. Ancak, kredi büyüklüğü üzerindeki etkiler ise ülkelere 
özgü olarak tespit edilmiştir. Finansal şokların uluslararası iletiminde kısa vadede varlık fiyatlarının oldukça önemli bir aktarım kanalı olduğu belirtilmiştir. Maliyet ve kredi büyüklüğü gibi diğer değişkenlerin katkıları ise uzun dönemde daha önemli hale gelmektedir.

Vansteenkiste ve Hiebert (2009), Avrupa'daki 10 ülke için 1989-2007 periyodunda konut fiyatlarının yayılımını araştırmışlardır. Ülkeler arası konut fiyatlarının birlikte hareketliliğini para birliğinin ticaret, finansal piyasalar ve genel ekonomik koşullar ile artan bağlantıların sonucunda olabileceği öne sürülmüş̧tür. Çalışmada konut talebi değişkeni olarak reel konut fiyatları, reel kişi başına harcanabilir gelir ve reel faiz oranı kullanılmıştır. Elde edilen sonuçlara göre, şoktan sonraki ilk 1-3 yıl içinde Avrupa bölgesinde konut fiyatlarının sınırlı bir yayılıma sahip olduğu görülmüştür.

Cesa-Bianchi vd. (2012) Çin'deki bir GSYİH şokunun Latin Amerika ekonomileri üzerindeki uzun dönem etkilerini analiz etmişlerdir. Buna göre, bu tip bir şokun Latin Amerika ekonomileri üzerindeki etkisi 1990'lı yılların ortalarından beri 3 kat artmıştır. Ayrıca, şokun ABD GSYİH üzerindeki uzun dönem etkileri ise yarıya inmiştir.

Sun vd. (2013) Avrupa'da ülkeler arasındaki bağlantıyı araştırmak için ticaret ve finansal ağırlık değişkenlerini birleştiren bir GVAR modeli ile çalışmışlardır. Elde ettikleri bulgulara göre, Avrupa' da çıtı büyümesi ve faiz oranları güçlü bir şekilde birlikte hareket etmektedir. Ancak, reel kredi büyümesi ve enflasyon arasında ise zayıf bir ilişki bulunmaktadır.

ABD kredi şokları ve iş çevrimi dalgalanmalarının açıklanmasında kredinin önemi konusunda yaptığı araştırmalarda Xu (2012)'ye göre, gelişen bankacılık sektörü ile birlikte ülkelerdeki uzun dönem faiz oranları, enflasyondaki değişim ve çıktı büyümesinin açıklanmasında banka kredileri oldukça önem arz etmektedir. Ayrıca, çalışmada ABD kredi şoklarının Birleşik Krallık, Avrupa, Japonya ve diğer gelişmiş ülke ekonomileri üzerinde yayılma etkisine sahip olduğunu gösteren güçlü kanitlar bulunmuştur.

\section{FINANSAL ÇEVRIMLER VE İŞ ÇEVRIMLERI ARASINDAKİ ETKİLEŞIMLLEIIN ANALIZi}

Çalışmanın bu bölümünde, finansal çevrimler ve makroekonomik çevrimler arasındaki etkileşimlerin Türkiye ekonomisi üzerindeki geçerliliğini sınamak amacıyla Granger Nedensellik Testi kullanılacaktır. Çalışmada finansal çevrimlerin analizine yönelik olarak reel varlık fiyatları, reel kredi hacmi endeksi, finansal stres endeksi ve konut fiyatları endeksi verileri kullanılmıştır. İş çevrimlerinin analizine yönelik olarak ise endüstriyel üretim endeksi, tüketici fiyat endeksi, reel faiz, reel efektif döviz kuru endeksi, tüketim endeksi, hükümet harcamaları endeksi, yatırım endeksi, ihracat endeksi, İthalat endeksi verileri kullanılmıştır. $\mathrm{Bu}$ aşamada öncelikle veriler tanitılacaktır.

\subsection{Serilerin Tanımları}

Çalışmada kullanılan tüm değişkenler aylık frekansta olup 2003:1 - 2015:12 dönemini kapsamaktadır. Analizde logaritmaları alınmış seriler $(2010=100)$ endeksi ile kullanılmıştır. Aşağıdaki tabloda kullanılan veri seti ve kaynağı belirtilmiştir. 
Tablo 1. Veri Seti

\begin{tabular}{|c|c|c|c|c|}
\hline Değişkenler & Kisaltma & Kaynak & Periyot & \begin{tabular}{|l|} 
Gözlem \\
Sayısı
\end{tabular} \\
\hline $\begin{array}{l}\text { Endüstriyel } \\
\text { Üretim } \\
\text { Endeksi }\end{array}$ & ipi & International Financial Statistics (IFS) & 2003:1-2015:12 & 156 \\
\hline $\begin{array}{l}\text { Tüketici Fiyat } \\
\text { Endeksi } \\
\text { (TÜFE) } \\
\end{array}$ & cpi & International Financial Statistics (IFS) & 2003:1-2015:12 & 156 \\
\hline $\begin{array}{l}\text { Reel Varlık } \\
\text { Fiyat Endeksi }\end{array}$ & rasset & $\begin{array}{lll}\text { International } & \text { Financial Statistics } \\
\text { (IFS)(Nominal Varlı Fiyatları / } \\
\text { TÜFE) }\end{array}$ & 2003:1-2015:12 & 156 \\
\hline $\begin{array}{lr}\text { Reel } & \text { Kredi } \\
\text { Hacmi Endeksi }\end{array}$ & rcrdt & $\begin{array}{l}\text { Türkiye Cumhuriyet Merkez Bankası } \\
\text { (TCMB) }\end{array}$ & 2003:1-2015:12 & 156 \\
\hline Reel Faiz & $\mathrm{r}$ & $\begin{array}{l}\text { Borsa İstanbul (BIST)(Nominal Faiz / } \\
\text { TÜFE) }\end{array}$ & 2003:1-2015:12 & 156 \\
\hline $\begin{array}{ll}\text { Finansal Stres } \\
\text { Endeksi }\end{array}$ & fse & Federal Reserve Bank of St. Louis & 2003:1-2015:12 & 156 \\
\hline $\begin{array}{lr}\text { Reel Efektif } \\
\text { Döviz Kuru } \\
\text { Endeksi-TÜFE } \\
\text { Bazlı } \\
\end{array}$ & rexc & $\begin{array}{l}\text { Türkiye Cumhuriyet Merkez Bankası } \\
\text { (TCMB) }\end{array}$ & 2003:1-2015:12 & 156 \\
\hline $\begin{array}{l}\text { Konut Fiyatları } \\
\text { Endeksi }\end{array}$ & kfe & $\begin{array}{l}\text { Real Estate Investment \& } \\
\text { Development Information Network } \\
\text { (REIDIN) }\end{array}$ & 2003:1-2015:12 & 156 \\
\hline $\begin{array}{l}\text { Tüketim } \\
\text { Endeksi }\end{array}$ & cons & $\begin{array}{l}\text { Türkiye Cumhuriyet Merkez Bankası } \\
\text { (TCMB) }\end{array}$ & 2003:1-2015:12 & 156 \\
\hline $\begin{array}{l}\text { Yatırım } \\
\text { Endeksi }\end{array}$ & i & $\begin{array}{l}\text { Türkiye Cumhuriyet Merkez Bankası } \\
\text { (TCMB) }\end{array}$ & 2003:1-2015:12 & 156 \\
\hline $\begin{array}{l}\text { Hükümet } \\
\text { Harcamaları } \\
\text { Endeksi }\end{array}$ & g & $\begin{array}{l}\text { Türkiye Cumhuriyet Merkez Bankası } \\
\text { (TCMB) }\end{array}$ & 2003:1-2015:12 & 156 \\
\hline $\begin{array}{l}\text { İhracat } \\
\text { Endeksi }\end{array}$ & $x$ & $\begin{array}{l}\text { Türkiye Cumhuriyet Merkez Bankası } \\
\text { (TCMB) }\end{array}$ & 2003:1-2015:12 & 156 \\
\hline İthalat Endeksi & $\mathrm{m}$ & $\begin{array}{l}\text { Türkiye Cumhuriyet Merkez Bankası } \\
\text { (TCMB) }\end{array}$ & 2003:1-2015:12 & 156 \\
\hline
\end{tabular}

Çalışmada ekonomi üzerindeki iş çevrimlerini analiz edebilmek için makroekonomik değişkenler olarak Endüstriyel Üretim Endeksi, Tüketici Fiyat Endeksi (TÜFE), Reel Faiz, Reel Efektif Döviz Kuru Endeksi-TÜFE Bazlı, Tüketim Endeksi, Yatırım Endeksi, Hükümet Harcamaları Endeksi, İhracat Endeksi, İthalat Endeksi kullanılmıştır. Finansal çevrimleri analiz edebilmek için finansal değişken olarak Reel Varlık Fiyat Endeksi, Reel Kredi Hacmi Endeksi, Finansal Stres Endeksi, Konut Fiyatları Endeksi kullanılmıştır. Finansal değişkenlerin seçilme nedeni aşağıdaki gibi özetlenebilir:

Çalışmada kullanılan finansal değişkenlerden Reel Kredi Hacmi endeksi, Claessens vd. (2012a)'nin işaret ettiği gibi bir ekonomide tasarruflar ile yatırımlar arasındaki ilişkiyi temsil eden en önemli finansal gösterge olduğu için; 
Reel varlık fiyat endeksi Avouyi-Dovi ve Matheron (2005)'un belirttiği gibi mal ve hizmet fiyatlarını etkileyerek ekonomik faaliyetler ve enflasyon üzerinde etkili olduğu için;

Ticaret ve sermaye piyasalarının giderek serbestleşmesi, gelişen teknoloji ve artan iletişim imkânları hem reel hem de finansal piyasaların küreselleşerek derinleşmesini sağlamıştır. Ülkelerin ticaret ve finans kanallarına bağımlılıklarının artması özellikle dişa açık gelişmekte olan ülkelerin küresel şoklara daha fazla maruz kalmalarına neden olmaktadır (Binici vd. 2016:1-2). Bu nedenle küresel olarak finansal stres dönemlerinin genel ekonomi üzerindeki etkilerinin anlaşılabilmesi önem taşımaktadır. Çalışmada küresel iktisadi faaliyetteki görünümün ve küresel finansal koşulların göstergesi olarak, Amerika Birleşik Devletleri Merkez Bankası tarafından yayınlanan finansal stres endeks verisi kullanılmıştır.

Konut fiyatları değişik kanallar aracılığı ile ekonomi üzerinde etkili olmaktadır. Kredi kısıtlarının bulunduğu bir ekonomide, konut eğer bir teminat olarak kullanılmakta ise, konut fiyatındaki değişiklikler doğrudan teminatın büyüklügünü ve dolayısı ile krediye erişimi etkileyebilmektedir. Bu kanalla konut fiyatları ekonomik dalgalanmalarda etkili olabilmektedir. Iacoviello (2004) çalışmasında konut fiyatlarının kredi kısıtları yoluyla tüketim hareketlerini etkilediğini belirtmiştir. Chen, Chen, ve Chou (2010) ise kredi kısıdının değişik toplulaştırılmış tüketimler üzerindeki asimetrik etkisini incelemiş ve dayanıklı tüketim ürünlerinin konut fiyat değişimlerinden belirgin olarak etkilendiğini, dayanıksız tüketim ürünlerinde ise böyle bir etki bulunmadığını göstermiştir. Ayrıca konut sektörüne bağlı olarak konut kredi piyasası da hızla gelişebilmektedir. Gelişmiş ülkelerde konut kredileri toplam kredi büyüklüğü içinde önemli bir paya sahip olmaktadır. Türkiye'de de 2000'li yılların başlarında itibaren konut kredileri hızla artmaya başlamış ve aynı süreçte kredi içindeki payları da artmıştır. Burada konut sektörüne bağlı kredi piyasasında doğrudan bir aşırı borçlanma olup olmadığı da ekonomik politikalar açısından önem arz etmektedir. Ayrıca finansal gelişme sürecinde konut kredileri üzerinde değişik finansal araçlar yazılabilmekte ve bu araçlar da finansal dalgalanmaları ve sistemik riskleri artırabilmektedir. Konut fiyatlarının önemli başka bir kanalı da zenginlik etkilerinden kaynaklanabilmektedir. Konut hane halkının en büyük varlık kalemlerinden birisini oluşturabilmekte ve konut fiyatlarındaki dalgalanmalar doğrudan zenginlik etkisi ile tüketim ve tasarruf üzerinde etkili olabilmektedir (Kılınç ve Tunç, 2013:3). Bu sayılan sebeplerden ve konut sektörünün hem kendi içindeki dinamiklerinin önemi hem de genel ekonomik yapıyı etkileyebilmedeki öneminden dolayı çalışmasında konut fiyatı endeksi finansal değişken olarak kullanılmıştır.

Logaritmaları alınan seriler Census X12 yöntemi kullanılarak mevsimsellikten arındırılmıştır. Söz konusu serilere Hodrick - Prescott Filtresib (HP Filtresi) uygulanarak serilerde trend hesaplanmıştır. İş çevrimleri serilerin trend değerinden sapmaları olarak belirlenmiştir. Zaman serilerine ait iş çevrimleri HP filtresi kullanılarak hesaplanan trend değerlerinin, mevsimsellikten arındırılmış serilerden çıkartılmasıyla elde edilmiştir. Serilerin durağanlığı genelleştirilmiş Dickey Fuller (ADF) birim kök testi ile sınanmıştır.

\footnotetext{
${ }^{\mathrm{b}}$ Literatürde, Baxter-King ve Christiano-Fitzgerald band geçiren filtreme yöntemlerinin de çevrimsel ve trend bileşeni hesaplamasında sıklıkla kullanıldığı bilinmektedir. Bu çalışmada, hem literatürde standart yöntem olarak öne çıkması ve kullanım kolaylığı nedeniyle hem de benzer çalışmalarla karşılaştırılabilir sonuçlar elde edilmesi amacıyla HP filtreleme yöntemi tercih edilmiştir.
} 


\subsection{Birim Kök Testi Sonuçları}

Seriler arasında ekonometrik olarak anlamlı ilişkilerin tespit edilebilmesi için serilerin durağan olması gerekmektedir. Zaman serilerinde birim kökün varlığı serilerin durağan olmadığı anlamına gelmektedir. Bu nedenle öncelikle serilerin durağan olup olmadıkları araştırılmalıdır.

Çalışmada serilerin durağanlığını test etmek ve kaçıncı dereceden durağan olduğunu belirlemek için yaygın olarak kullanılan Genişletilmiş Dickey-Fuller (ADF) birim kök testi uygulanmıştır. ADF için sıfır hipotezi birim kökün var olduğunu yani serinin durağan olmadığını; alternatif hipotez ise birim kökün yokluğunu yani serinin durağan olduğunu ifade etmektedir. Eğer bulunan test istatistik değeri \%1, \%5 ve \%10 kritik değerlerinden küçükse sıfir hipotezi reddedilmektedir. Hatalar arasındaki otokorelasyon sorununu gideren optimal gecikme uzunluğu, seriler aylık verilerden oluştuğu için maksimum 13 olmak üzere Schwarz Bilgi Kriteri (SIC) ile belirlenmiştir.

Grafik inceleme sonucunda tüm serilerinde belirgin bir trend söz konusudur. Bu nedenle uygulanacak birim kök testlerinde sabit terim ve trend dikkate alınmıştır. Serilerin birim köke sahip olup olmadıklarını belirlemeye yönelik uygulanan ADF birim kök testi sonuçları Tablo 2 ' de yer almaktadir.

Tablo 2. ADF Birim Kök Testi

\begin{tabular}{|c|c|c|c|c|c|}
\hline \multirow{2}{*}{ Değişkenler } & \multicolumn{2}{|l|}{$\mathrm{ADF}$} & \multirow{2}{*}{ Değişkenler } & \multicolumn{2}{|l|}{ ADF } \\
\hline & Düzey & Trend ve Sbt Terim & & Fark & Trend ve Sbt Terim \\
\hline lipi & $-1.3924(0.5846)$ & $-3.6453(0.0295)^{* *}$ & $\Delta$ lipi & $-2.6640(0.0829)^{* * *}$ & $-4.0522(0.0092)^{*}$ \\
\hline lcpi & $-1.6486(0.4553)$ & $-4.3746(0.0032)^{*}$ & $\Delta \mathrm{lcpi}$ & $-9.6697(0.0000)^{*}$ & $-9.8195(0.0000)^{*}$ \\
\hline rasset & $-0.913(0.7820)$ & $-3.779(0.0202)^{* *}$ & $\Delta$ rasset & $-11.308(0.000)^{*}$ & $-11.4018(0.0000)^{*}$ \\
\hline lrcrdt & $-4.9402(0.0001)^{*}$ & $-4.0870(0.0082)^{*}$ & $\Delta$ lrcrdt & $-2.0647(0.2593)$ & $-5.5982(0.0000)^{*}$ \\
\hline lr & $-2.4463(0.1309)$ & $-2.0131(0.5892)$ & $\Delta \mathrm{lr}$ & $-8.5965(0.0000)^{*}$ & $-8.8258(0.0000)^{*}$ \\
\hline fse & $-2.303(0.1723)$ & $-2.362(0.3977)$ & $\Delta$ fse & $-10.261(0.0000)^{*}$ & $-10.229(0.0000)^{*}$ \\
\hline lrexc & $-2.9600(0.0411)^{* *}$ & $-3.3129(0.0680)^{* * *}$ & $\Delta$ lrexc & $-9.5874(0.0000)^{*}$ & $-9.7398(0.0000)^{*}$ \\
\hline $1 \mathrm{kfe}$ & $1.2576(0.9984)$ & $-0.2869(0.9904)$ & $\Delta \mathrm{lkfe}$ & $-3.4342(0.0112)^{* *}$ & $-3.8761(0.0153)^{* *}$ \\
\hline lcons & $-1.4688(0.5467)$ & $-3.7244(0.0238)^{* *}$ & $\Delta$ lcons & $-4.5386(0.0003)^{*}$ & $-4.6460(0.0013)^{*}$ \\
\hline $\lg$ & $-0.2561(0.9272)$ & $-3.0212(0.1300)$ & $\Delta \lg$ & $-4.4250(0.0004)^{*}$ & $-4.4576(0.0025)^{*}$ \\
\hline li & $-2.4242(0.1369)$ & $-3.9817(0.0113)^{* *}$ & $\Delta \mathrm{li}$ & $-3.9204(0.0024)^{*}$ & $-3.9148(0.0138)^{* *}$ \\
\hline $\operatorname{lm}$ & $-1.4147(0.5736)$ & $-3.4392(0.0502)^{* *}$ & $\Delta \mathrm{lm}$ & $-3.6139(0.0066)^{*}$ & $-3.6120(0.0322)^{* *}$ \\
\hline lx & $-0.1475(0.9410)$ & $-4.2766(0.0044)^{*}$ & $\Delta \mathrm{lx}$ & $-8.9693(0.0000)^{*}$ & $-8.9611(0.0000)^{*}$ \\
\hline
\end{tabular}

Tablo 2'de belirtilen ADF testi sonuçlarında, “*” işareti ile belirtilenler \%1 kritik düzeyde istatistiksel olarak anlamlı olanları, “**” işareti \%5 kritik düzeyde istatistiksel olarak anlamlı olanları, “***” işareti ise \%10 kritik düzeyde istatiksel olarak anlamlı olanları belirtmek için kullanılmıştır. Test sonuçları serilerin düzeydeki ve 1 . Farkları alındığı durumdaki durağanlıklarını göstermektedir. Çalışmanın 5.4. bölümünde belirtildiği üzere, Granger Nedensellik Testinde 1. Farkları alınan seriler arasındaki ilişkiler üzerinde durulmuştur. 


\subsection{Uygun Gecikme Sayısının Belirlenmesi}

Çalışmada en uygun gecikme süresini belirlemek amacıyla LR (Ardışık modifiye edilmiş LR test istatistiği), FPE (Son Tahmin Hata Kriteri), AIC (Akaike Bilgi Kriteri), SIC (Schwarz Bilgi Kriteri) ve HQ (Hannan-Quinn Bilgi Kriteri) ölçütleri kullanılmıştır.

Tablo 3. Gecikme Uzunlukları Testi Sonuçları

\begin{tabular}{|c|c|c|c|c|c|}
\hline $\begin{array}{c}\text { Gecikme } \\
\text { Uzunluğu }\end{array}$ & LR & FPE & AIC & SC & HQ \\
\hline $\mathbf{0}$ & NA & $5.66 \mathrm{e}-32$ & -3.505 .680 & -3.453 .027 & -3.484 .287 \\
\hline $\mathbf{1}$ & 1485.064 & $7.93 \mathrm{e}-36$ & -4.393 .891 & -3.998 .988 & -4.233 .443 \\
\hline $\mathbf{2}$ & 1282.968 & $1.86 \mathrm{e}-39$ & -5.234 .653 & $-\mathbf{4 4 . 9 7 5 0 1}$ & -4.935 .150 \\
\hline $\mathbf{3}$ & 551.8351 & $1.20 \mathrm{e}-40$ & -5.522 .008 & -4.442 .607 & -5.083 .450 \\
\hline $\mathbf{4}$ & 295.9745 & $6.60 \mathrm{e}-41$ & -5.608 .496 & -4.186 .846 & -5.030 .883 \\
\hline $\mathbf{5}$ & 324.1206 & $1.88 \mathrm{e}-41$ & -5.780 .267 & -4.016 .367 & -5.063 .598 \\
\hline $\mathbf{6}$ & 297.1543 & $4.96 \mathrm{e}-42$ & -5.988 .880 & -3.882 .731 & -5.133 .156 \\
\hline $\mathbf{7}$ & $\mathbf{2 0 6 . 3 6 5 6}$ & $\mathbf{3 . 7 7 e}-\mathbf{4 2}$ & $\mathbf{- 6 1 . 3 5 7 1 2}$ & -3.687 .313 & $-\mathbf{5 1 . 4 0 9 3 3 ^ { * }}$ \\
\hline
\end{tabular}

* işareti ilgili gecikmenin uygun olduğunu ifade etmektedir.

Tablo 3'te uygun gecikme uzunluğu için Schwarz bilgi kriteri haricinde uygun gecikme sayısının 7 gecikme olduğu görülmektedir. Bu nedenle uygun gecikme sayısı 7 olarak belirlenmiştir.

\subsection{Granger Nedensellik Testi}

Granger (1969)'a göre nedensellik testi, eğer $Y_{t}$ değişkeni $X_{t}$ değişkeninin geçmiş değerleri kullanıldığında kullanılmadığı duruma göre daha iyi tahmin edebiliyorsa $X_{t}, Y_{t}$ 'nin Granger nedenidir. Burada $\mu_{1 t}$ ve $\mu_{2 t}$ hata terimlerinin birbiriyle ilişkisiz olduğu varsayımı altında aşağıdaki gibi ifade edilebilir (Hafer, 1982):

$$
\begin{gathered}
Y_{t}=\sum_{i=1}^{n} \alpha_{i} X_{t-i}+\sum_{j=1}^{n} \beta_{j} Y_{t-j}+\mu_{1 t} \\
X_{t}=\sum_{i=1}^{m} \lambda_{i} X_{t-i}+\sum_{j=1}^{m} \delta_{j} Y_{t-j}+\mu_{2 t}
\end{gathered}
$$

$X_{t}$ ve $Y_{t}$ değişkenlerinin durağan olduğu varsayımı ile Granger nedensellik testi (1) ve (2) numaralı Vektör Otoregresif (VAR) modellerinin tahminini gerektirmektedir. Buna göre aşağıda belirtilen durumlar ortaya çıabilmektedir:

1) Eğer (1) numaralı denklemdeki $X$ 'in tahmin edilen katsayıları bir küme olarak istatistiksel bakımdan sıfırdan farklıysa (yani $\sum \alpha_{i} \neq 0$ ) ve (2) numaralı denklemdeki gecikmeli $Y$ 'nin tahmin edilen katsayıları bir küme olarak istatistiksel bakımdan sıfırdan farklı değilse (yani $\sum \delta_{j}=0$ ), bu durum $X^{\prime}$ 'den $Y^{\prime}$ ye doğru tek yönlü nedensellik göstermektedir. 
2) Tersine, eğer (1) numaralı denklemdeki gecikmeli $X^{\prime}$ 'in tahmin edilen katsayıları bir küme olarak istatistiksel bakımdan sıfırdan farklı değilse (yani $\sum \alpha_{i}=0$ ) ve (2) numaralı denklemdeki $Y$ 'nin tahmin edilen katsayıları bir küme olarak istatistiksel bakımdan sıfırdan farklıysa (yani $\sum \delta_{j} \neq 0$ ), bu durum $Y$ 'den $X^{\prime}$ 'e doğru tek yönlü nedensellik göstermektedir.

3) Her iki regresyondaki $X$ ve $Y$ katsayı kümeleri istatistiksel bakımdan sıfırdan anlamlı derecede farklıysa, bu durum çift yönlü nedensellik göstermektedir.

4) Son olarak, her iki regresyondaki $X$ ve $Y$ katsayı kümeleri istatistiksel bakımdan sıfırdan anlamlı değilse, bu durum nedensellik ilişkisinin olmadığını göstermektedir.

Granger nedensellik testinde değişkenlerin durağan olması gerekmektedir. Ayrıca gecikme sayısına duyarlı bir testtir. Bu aşamada, birinci dereceden farkları alınan seriler arasındaki nedensellik ilişkilerinin yönünü belirlemek amacıyla uygulanan Granger nedensellik testinden elde edilen sonuçlara göre, nedensellik ilişkisi bulunan değişkenler Tablo 4'te belirtilmiştir.

Tablo 4. Nedensellik Testi Sonuçları

\begin{tabular}{|c|c|c|c|c|c|c|c|}
\hline Bağımsız Değ. & \begin{tabular}{|l}
$\begin{array}{l}\text { Bağımlı } \\
\text { Değ. }\end{array}$ \\
\end{tabular} & F-İst. & Olasılık & \begin{tabular}{|l|} 
Bağımsız \\
Değ.
\end{tabular} & \begin{tabular}{|l|} 
Bağımlı \\
Değ.
\end{tabular} & F-İst. & Olasılık \\
\hline $\mathrm{D}(\mathrm{LI})$ & D(LIPI) & 15,32669 & 0,032 & $\mathrm{D}$ (LKFE) & $\mathrm{D}(\mathrm{LCONS})$ & 22,86373 & 0,0018 \\
\hline $\mathrm{D}$ (RASSET) & $\mathrm{D}(\mathrm{LCPI})$ & 16,87799 & 0,0182 & $\mathrm{D}(\mathrm{LG})$ & D(LCONS) & 44,2116 & 0 \\
\hline D(LRCRDT) & $\mathrm{D}(\mathrm{LCPI})$ & 17,56536 & 0,0141 & $\mathrm{D}(\mathrm{LI})$ & $\mathrm{D}$ (LCONS) & 15,40118 & 0,0312 \\
\hline $\mathrm{D}(\mathrm{LR})$ & $\mathrm{D}(\mathrm{LCPI})$ & 19,66222 & 0,0063 & $\mathrm{D}(\mathrm{LM})$ & D(LCONS) & 20,24266 & 0,0051 \\
\hline $\mathrm{D}$ (FSE) & $\mathrm{D}(\mathrm{LCPI})$ & 14,69762 & 0,0401 & $\mathrm{D}(\mathrm{LX})$ & D(LCONS) & 24,9157 & 0,0008 \\
\hline D(LKFE) & $\mathrm{D}(\mathrm{LCPI})$ & 28,84475 & 0,0002 & $\mathrm{D}$ (LIPI) & $\mathrm{D}(\mathrm{LG})$ & 31,01936 & 0,0001 \\
\hline D(LCONS) & $\mathrm{D}(\mathrm{LCPI})$ & 22,25439 & 0,0023 & $\mathrm{D}(\mathrm{LM})$ & $\mathrm{D}(\mathrm{LG})$ & 17,17744 & 0,0163 \\
\hline $\mathrm{D}(\mathrm{LG})$ & $\mathrm{D}(\mathrm{LCPI})$ & 36,92516 & 0 & $\mathrm{D}(\mathrm{LCPI})$ & $\mathrm{D}(\mathrm{LI})$ & 115,0589 & 0 \\
\hline $\mathrm{D}(\mathrm{LI})$ & $\mathrm{D}(\mathrm{LCPI})$ & 15,62661 & 0,0288 & $\mathrm{D}$ (LRCRDT) & $\mathrm{D}(\mathrm{LI})$ & 21,63342 & 0,0029 \\
\hline $\mathrm{D}(\mathrm{LM})$ & $\mathrm{D}(\mathrm{LCPI})$ & 20,24466 & 0,0051 & $\mathrm{D}(\mathrm{LR})$ & $\mathrm{D}(\mathrm{LI})$ & 14,49856 & 0,043 \\
\hline $\mathrm{D}(\mathrm{LX})$ & $\mathrm{D}(\mathrm{LCPI})$ & 24,52771 & 0,0009 & $\mathrm{D}(\mathrm{LKFE})$ & $\mathrm{D}(\mathrm{LI})$ & 15,55968 & 0,0295 \\
\hline D(LCONS) & D(RASSET) & 22,93242 & 0,0018 & $\mathrm{D}(\mathrm{LCONS})$ & $\mathrm{D}(\mathrm{LI})$ & 16,38889 & 0,0218 \\
\hline $\mathrm{D}(\mathrm{LIPI})$ & D(LRCRDT) & 13,99551 & 0,0513 & $\mathrm{D}(\mathrm{LG})$ & $\mathrm{D}(\mathrm{LI})$ & 34,16059 & 0 \\
\hline $\mathrm{D}$ (FSE) & $\mathrm{D}$ (LRCRDT) & 16,89527 & 0,0181 & $\mathrm{D}(\mathrm{LM})$ & $\mathrm{D}(\mathrm{LI})$ & 17,24396 & 0,0159 \\
\hline $\mathrm{D}(\mathrm{LG})$ & $\mathrm{D}$ (LRCRDT) & 15,05156 & 0,0353 & $\mathrm{D}(\mathrm{LX})$ & $\mathrm{D}(\mathrm{LI})$ & 21,22008 & 0,0035 \\
\hline D(LKFE) & $\mathrm{D}$ (FSE) & 42,25325 & 0 & D(LIPI) & $\mathrm{D}(\mathrm{LM})$ & 13,6741 & 0,0573 \\
\hline $\mathrm{D}(\mathrm{LI})$ & $\mathrm{D}$ (FSE) & 16,91118 & 0,018 & D(LCPI) & $\mathrm{D}(\mathrm{LM})$ & 67,52673 & 0 \\
\hline $\mathrm{D}(\mathrm{LX})$ & $\mathrm{D}$ (FSE) & 14,84855 & 0,038 & D(LKFE) & $\mathrm{D}(\mathrm{LM})$ & 14,30379 & 0,046 \\
\hline D(FSE) & D(LKFE) & 26,40094 & 0,0004 & $\mathrm{D}(\mathrm{LG})$ & $\mathrm{D}(\mathrm{LM})$ & 50,19841 & 0 \\
\hline $\mathrm{D}(\mathrm{LI})$ & $\mathrm{D}$ (LKFE) & 21,30214 & 0,0033 & $\mathrm{D}(\mathrm{LX})$ & $\mathrm{D}(\mathrm{LM})$ & 15,18665 & 0,0337 \\
\hline $\mathrm{D}(\mathrm{LM})$ & D(LKFE) & 24,28995 & 0,001 & D(LIPI) & $\mathrm{D}(\mathrm{LX})$ & 14,50322 & 0,0429 \\
\hline $\mathrm{D}(\mathrm{LX})$ & D(LKFE) & 16,46981 & 0,0212 & $\mathrm{D}(\mathrm{LCPI})$ & $\mathrm{D}(\mathrm{LX})$ & 51,92669 & 0 \\
\hline $\mathrm{D}(\mathrm{LCPI})$ & $\mathrm{D}$ (LCONS) & 121,7725 & 0 & D(LKFE) & $\mathrm{D}(\mathrm{LX})$ & 20,64616 & 0,0043 \\
\hline
\end{tabular}




\begin{tabular}{|l|l|l|l|l|l|l|l|}
\hline $\mathrm{D}$ (RASSET) & $\mathrm{D}$ (LCONS) & 16,79025 & 0,0188 & $\mathrm{D}$ (LCONS) & $\mathrm{D}(\mathrm{LX})$ & 12,97376 & 0,0728 \\
\hline $\mathrm{D}($ LRCRDT $)$ & $\mathrm{D}$ (LCONS) & 20,45624 & 0,0047 & $\mathrm{D}(\mathrm{LG})$ & $\mathrm{D}(\mathrm{LX})$ & 49,14234 & 0 \\
\hline $\mathrm{D}(\mathrm{LR})$ & $\mathrm{D}$ (LCONS) & 19,63313 & 0,0064 & $\mathrm{D}(\mathrm{LM})$ & $\mathrm{D}(\mathrm{LX})$ & 14,26129 & 0,0467 \\
\hline
\end{tabular}

Granger nedensellik sonuçlarına göre, reel varlık fiyat endeksi, reel kredi hacmi endeksi, finansal stres endeksi ve konut fiyatları endeksi finansal değişkenleri tüketici fiyat endeksindeki dalgalanmalara sebep olan açıklayıcı bir değişkendir.

Reel kredi hacmi endeksi, reel varlık fiyat endeksi ve konut fiyatları endeksi finansal değişkenleri tüketim endeksindeki dalgalanmalara sebep olan açıklayıcı bir değişkendir.

Reel kredi hacmi endeksi ve konut fiyatları endeksi finansal değişkenleri yatırımdaki dalgalanmalara sebep olan açıklayıcı bir değişkendir.

Konut fiyatları endeksi finansal değişkeni ithalat ve ihracattaki dalgalanmalara sebep olan açılayıcı bir değişkendir.

Tablo 5' te değişkenlerin yönü ile ilgili sonuçlar şematik olarak gösterilmiştir.

Tablo 5. Seriler Arasındaki İlişkilerin Yönü

\begin{tabular}{|c|c|c|}
\hline \multirow{10}{*}{ Tüketici Fiyat Endeksi } & 4 & Tüketim \\
\hline & & Yatırım \\
\hline & & Ithalat \\
\hline & & İhracat \\
\hline & & Reel Varlık Fiyat Endeksi \\
\hline & & Reel Kredi Hacmi Endeksi \\
\hline & & Reel Faiz \\
\hline & & Finansal Stres Endeksi \\
\hline & & Konut Fiyatları Endeksi \\
\hline & & Hükümet Harcamaları \\
\hline \multirow{7}{*}{ Tüketim } & & Yatırım \\
\hline & & İhracat \\
\hline & & Reel Kredi Hacmi Endeksi \\
\hline & & Reel Faiz \\
\hline & & Konut Fiyatları Endeksi \\
\hline & & Hükümet Harcamaları \\
\hline & & İthalat \\
\hline \multirow{5}{*}{ Yatırım } & & Reel Kredi Hacmi Endeksi \\
\hline & & Reel Faiz \\
\hline & & Hükümet Harcamaları \\
\hline & & Ithalat \\
\hline & & İhracat \\
\hline \multirow[t]{2}{*}{ Hükümet Harcamaları } & & İthalat \\
\hline & & Endüstriyel Üretim Endeksi \\
\hline \multirow[t]{2}{*}{ İthalat } & & İhracat \\
\hline & & Endüstriyel Üretim Endeksi \\
\hline
\end{tabular}




\begin{tabular}{|c|c|c|}
\hline \multirow[t]{2}{*}{ İhracat } & & Endüstriyel Üretim Endeksi \\
\hline & & Hükümet Harcamaları \\
\hline Endüstriyel Üretim Endeksi & & Yatırım \\
\hline \multirow[t]{2}{*}{ Reel Varlık Fiyat Endeksi } & & Tüketim \\
\hline & & Endüstriyel Üretim Endeksi \\
\hline \multirow[t]{3}{*}{ Reel Kredi Hacmi Endeksi } & & Finansal Stres Endeksi \\
\hline & & Hükümet Harcamaları \\
\hline & & Konut Fiyatları Endeksi \\
\hline \multirow[t]{2}{*}{ Finansal Stres Endeksi } & & Yatırım \\
\hline & & İhracat \\
\hline \multirow{3}{*}{ Konut Fiyatları Endeksi } & & Yatırım \\
\hline & $\rightarrow$ & İthalat \\
\hline & 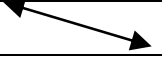 & İhracat \\
\hline
\end{tabular}

Test sonuçlarına göre aynı zamanda, tüketimdeki dalgalanmalar reel varlık fiyat endeksindeki dalgalanmalara sebep olan açıklayıcı bir değişkendir. Benzer şekilde, yatırım, ithalat ve ihracattaki dalgalanmalar konut fiyatları endeksindeki dalgalanmalara sebep olan açıklayıcı bir değişkendir.

\section{SONUÇ}

Türkiye'de 2003:1 - 2015:12 döneminde iş çevrimi ve finansal çevrimler arasındaki etkileşimlerin araştırılması amacıyla Granger nedensellik testi kullanılan çalışmada makroekonomik değişkenler olarak Endüstriyel Üretim Endeksi, Tüketici Fiyat Endeksi (TÜFE), Reel Faiz, Reel Efektif Döviz Kuru Endeksi-TÜFE Bazlı, Tüketim Endeksi, Yatırım Endeksi, Hükümet Harcamaları Endeksi, İhracat Endeksi, İthalat Endeksi; finansal değişken olarak Reel Varlık Fiyat Endeksi, Reel Kredi Hacmi Endeksi, Finansal Stres Endeksi, Konut Fiyatları Endeksi kullanılmıştır.

Makroekonomik değişkenler ve finansal değişkenler arasındaki ilişkiler incelendiğinde, reel kredi hacmi endeksi ve konut fiyatları endeksinin makroekonomik değişkenler üzerinde dalgalanmalara sebep olan bir açıklayıcı değişken olarak öne çıktığı görülmektedir. Buna göre, reel kredi hacmi endeksi finansal değişkeni tüketici fiyat endeksi, tüketim ve yatırımdaki dalgalanmalara sebep olan açıklayıcı bir değişkendir. Konut fiyatları endeksi ise tüketici fiyat endeksi, tüketim, ithalat, ihracat ve yatırımdaki dalgalanmalara sebep olan açıklayıcı bir değişkendir.

Buradan elde edilen sonuç, Mishkin (1996)'nın belirttiği konut ve arazi fiyatlarındaki artışların hane halkının servetinde artışa neden olacağı buna bağlı olarak da tüketim harcamalarının yükseleceği yönündeki görüşü destekler niteliktedir. Konut fiyatlarının yükselmesi/düşmesi, hane halklarının servet/yükümlülük ve beklentilerindeki değişimlere bağlı olarak ekonomik değişkenleri etkileyebilmektedir.

Çalışmadan elde edilen diğer bir sonuç ise finansal değişkenlerin birbirleri arasındaki ilişkiler ile ilgilidir. Buna göre konut fiyatları endeksi ve reel kredi hacmi endeksi arasında çift yönlü bir nedensellik ilişkisi bulunmaktadır. Ayrıca, konut fiyatları endeksi ve finansal stres endeksi finansal değişkenleri reel kredi hacmi endeksindeki dalgalanmalara sebep olan açıklayıcı bir değişkendir. 
Ekonomiler dinamik yapıda olduğundan birçok değişkenin etkisi altında çeşitli şoklara maruz kalabilmektedir. Çalışma finansal dalgalanmaları temsilen dört adet finansal değişken kullanılmıştır. Makroekonomik değişkenler ve finansal değişkenler arasındaki bu nedensellik ilişkisi göz önünde bulundurulduğunda iş çevrimleri ve finansal çevrimler üzerine yapılacak çalışmalarda reel kredi hacmi endeksi ve konut fiyatları endeksinin ekonomideki iş çevrimlerinin analiz edilmesinde açıklayıcı değişken olarak kullanılabileceği önerilmektedir.

\section{KAYNAKÇA}

Aikman, D., Haldane, A.G. ve Nelson, B. (2014). "Curbing the Credit Cycle", The Economic Journal, Vol. 125, Issue 585, June 2015, 1072-1109.

Aizenman, J., Pinto, B. ve Vladyslav, S. (2013). "Financial Sector Ups and Downs and the Real Sector in the Open Economy: Up by the Stairs, Down by the Parachute", Emerging Markets Review, 16(C), 1-30.

Alessi, L.ve Detken, C. (2011). "Real Time Early Warning Indicators for Costly Asset Price Boom/Bust Cycles: A Role For Global Liquidity", European Journal of Political Economy, 27(3), 520-33.

Altuğ, G.S. (2010). Business Cycles: Fact, Fallacy and Fantasy, Wold Scientific Publishing Co. Pte. Ltd, 8-10,16-18.

Alvarez, L.J. ve Cabrero, A. (2010). “Does Housing Really Lead The Business Cycle?”, Banco De Espana, Madrid, 2010.

Artis, M., Chouliarakis, G. ve Harischandra, P.K.G. (2011). “Business Cycle Synchronization Since 1880", The Manchester School, Vol 79, No. 2, 173-207 March 2011, 2.

Artis, M., Marcellino, M. ve Proietti, T. (2004). “Dating Business Cycles: A Methodological Contribution with an Application to the Euro Area", Oxford Bullettin of Economics $\mathcal{E}$ Statistics, Vol. 66, No.4, 537-565.

Auroba, S.B., Diebold, F.X., Kose, M.A. ve Terrones, M.E. (2011). “Globalization, the Business Cycle, and Macroeconomic Monitoring", IMF Working Paper, WP/11/25.

Avouyi Dovi, S., \& Matheron, J. (2005). "Interactions between business cycles, financial cycles and monetary policy: stylised facts”, BIS Çalışma Tebliği, Sayı 22, 273-298.

Bank for International Settlements (BIS) (2001). “71st Annual Report 1 April 2000 - 31 March 2001", BIS Report, Basel, 123-127.

Bayoumi, T. ve Bui, T. (2010). “Deconstructing The International Business Cycle: Why Does A U.S. Sneeze Give The Rest Of The World A Cold?", IMF Working Paper, WP/10/239.

Binici, M. Haçhasanoğlu, Y.S. Kütük, S. (2016), “Türkiye'de Finansal Çevrimler ve İş Çevrimleri: Ne Kadar Farklı, Ne Kadar Bağlantılı?, TCMB Ekonomi Notları, Sayı: 201626, 02 Eylül 2016, 1-2.

Borio, C. ve Lowe, P. (2002). "Assessing the risk of banking crises”, BIS Quarterly Review, December, $43-54$.

Borio, C. ve Lowe, P. (2004). "Securing Sustainable Price Stability, Should Credit Come back from the Wilderness?", BIS Working Paper, No 157. 
Borio, C. ve Drehmann, M. (2009). "Assessing the Risk of Banking Crises - Revisited", BIS Quarterly Review, March 2009, 29-46.

Borio, C. (2012). "The Financial Cycle and Macroeconomics: What have we learnt?", Monetary and Economic Department, BIS Working Paper, No 395, 2-3.

Borio, C., Disyatat, P. ve Juselius, M. (2013). "Rethinking Potential Output: Embedding Information about the Financial Cycle", BIS Working Paper, No 404.

Borio, C. ve White, W. (2003). "Whither monetary and financial stability? The implications of evolving policy regimes", BIS Working Paper, No 147, February 2004.

Bracke, P. (2013). “How Long Do Housing Cycles Last? A Duration Analysis for 19 OECD Countries", Journal of Housing Economics, 22, 213-30.

Burns, A. ve Mitchell, W. (1946). “Measuring Business Cycles”, NBER, New York, 3.

Cashin, P., Mohaddes, K. ve Raissi, M. (2012). “The Global Impact of the Systemic Economies and MENA Business Cycles", IMF Working Paper, WP/12/255.

Cesa-Bianchi, A., Pesaran, M.H., Rebucci, A. ve Xu. T. (2012). “China's emergence in the world economy and business cycles in Latin America", Journal of LACEA Economia.

Chen, N., Chen, S., Chou, Y. (2010), “House Prices, Collateral Constraints, and the Asymmetric Effect on Consumption", Journal of Housing Economics, 19, s.26-37.

Claessens, S., Kose, M.A. ve Terrones, M.E. (2011a). "Financial cycles: What? How? When?", IMF Working Paper, WP/11/76,3.

Claessens, S., Kose, M.A. ve Terrones, M.E. (2011b). “How do business and financial cycles interact?", IMF Working Paper, WP/11/88,11,12.

Claessens, S., Kose, M.A. ve Terrones, M.E. (2012a). "How do business and financial cycles interact?" Journal of International Economics, 87, 178-190.

Cuevas, A., Messmacher, M. ve Werner, A. (2002). “Macroeconomic Synchronization between Mexico and its NAFTA Partners". World Bank, mimeo.

Dées, S., di Mauro, F., Pesaran, M.H. ve Smith, L.V. (2005). “Exploring The International Linkages of The Euro Area: A Global VAR Analysis", European Central Bank, Working Paper Series, No. 568, December 2005, 5-38.

Dées, S., di Mauro, F., Pesaran, M.H. ve Smith, L.V. (2007). “Exploring The International Linkages of The Euro Area: A Global VAR Analysis", Journal of Applied Econometrics, 22, 1-38, 2007, Wiley InterScience, http://onlinelibrary.wiley.com/doi/10.1002/jae.932/pdf (19.11.2015)

Dées, S. (2015). “Credit, Asset Prices and Business Cycle at the Global Level”, European Central Bank, August 2015. 2-5.

Dell' Arriccia, G. Igan, D. Laeven, L. ve Tong, H. (2012). “Policies for macrofinancial stability: How to deal with credit booms", IMF Discussion Note, April.

Detken, C. ve Smets, F. (2004). “Asset Price Booms and Monetary Policy”, ECB Working Paper, No 364. 
Drehmann, M. ve Juselius, M. (2012). "Measuring liquidity constraints in the economy: the dept service ratio and financial crises", BIS Quarterly Review, September, 21-35.

Drehmann, M. Borio, C. Tsatsaronis, K. (2012). “Characterising the financial cycle: don't lose sight of the medium term!", BIS Working Papers No: 380, June 2012.

Drehmann, M. ve Tsatsaronis, K. (2014). “The Credit-to-GDP Gap and Countercyclical Capital Buffers: Questions and Answers", BIS Quarterly Review, March 2014.

English, W., Tsatsaronis, K. ve Zoli, E.(2005). “Assessing the Predictive Power of Measures of Financial Conditions For Macroeconomic Variables", BIS Papers, No 22.

Galesi, A. ve Sgherri, S. (2009). “Regional Financial Spillovers Across Europe: A Global VAR Analysis", IMF Working Paper, WP/09/23.

Goodhart, C. ve Hofmann, B. (2008). "House Prices, Money, Credit, and the Macroeconomy", Oxford Review of Economic Policy, 24, 180-205.

Granger, C. W. (1969). "Investigating causal relations by econometric models and crossspectral methods", Econometrica: Journal of the Econometric Society, 424-438.

Greenwood-Nimmo, M., Nguyen, V.H. ve Shin Y. (2012a). "International Linkages of the Korean Economy: The Global Vector Error-Correcting Macroeconometric Modelling Approach", Melbourne Institute Working Paper Series, WP2012n18, Melbourne Institute of Applied Economic and Social Research, The University of Melbourne.

Hafer, R.W. (1982). "The Role of Fiscal Policy in the St. Louis Equation," Review Federal Reserve Bank of St. Louis, January 1982, 17-22.

Harding, D. ve Pagan, A. (2002a). "Dissecting the Cycle: A Methodological Investigation", Journal of Monetary Economics, Vol. 49, 365-381.

Hirata, H., Kose, M.A. ve Otrok, C. (2013). “Regionalization vs. Globalization”, IMF Working Paper, WP/13/19.

Iacoviello, M., (2004), “Consumption, House Prices, and Collateral Constraints: A Structural Econometric Analysis", Journal of Housing Economics, 13, 304-320.

Jordá, O. Schularick, M. ve Taylor, A. M. (2011). "When credit bites back: Leverage, business cycles and crises". Federal Reserve Bank of San Francisco Working Paper Series, 2011-27.

Knoop, T.A. (2010). Recessions and Depressions : Understanding Business Cycles, 2nd Ed., ABC CLIO, LLC, Santa Barbara, California, USA,3-5,12-15, 33-46, 56-63, 74, 87-88, 97-99, 104106.

Lucas, R.E. (1977). “Understanding Business Cycles”, Carnegie-Rochester Conference Series on Public Policy, vol.5,10.

Male, R. (2011). “Developing Country Business Cycles: Characterizing the Cycle”, Emerging Markets Finance and Trade, Vol. 47, 20-39.

Mishkin, F.S. (1996). "The Channels of Monetary Transmission: Lesson for Monetary Policy", NBER Working Paper, No: 5464, ss. 1-27. 
Rana, P.B. (2007). "Economic Integration and Syncronization of Business Cycles in East Asia", Journal of Asian Economics, Vol. 18, No.5, 711-725.

Schularick, M. ve Taylor, A. M. (2012). “Credit Booms Gone Bust: Monetary Policy, Leverage Cycles and Financial Crises, 1870-2008", American Economic Review, 102(2), 1029-1061.

Stremmel, H. (2015). “Capturing The Financial Cycle In Europe”, ECB Working Paper Series, No 1811 / June 2015, 5.

Sun, Y., Heinz, F.F. ve Ho, G. (2013). “Cross-country linkages in Europe: A Global VAR analysis", IMF Working Paper, WP/13/194.

Vansteenkiste, I. ve Hiebert, P. (2009). “Do House Price Developments Spill Over Across Euro Area Countries? Evidence From A Global VAR", European Central Bank, Working Paper Series, No 1026.

Wezel, T. (2014). “Rightsizing the Countercyclical Capital Buffer for EU Countries - A Residual Loss Approach", European Central Bank, Manuscript.

$\mathrm{Xu}, \mathrm{T}$. (2012). "The role of credit in international business cycle", Cambridge Working Papers, 1202, Faculty of Economics, University of Cambridge. 